\title{
ASYLUM POLICY IN EUROPE - THE COMPETENCES OF THE EUROPEAN UNION AND INEFFICIENCY OF THE DUBLIN SYSTEM
}

\begin{abstract}
Nika Bačić*
Summary: This article demonstrates how the transfer of competences in asylum policy from Member States to the European Union, although guided by the objective of improving and harmonising diverse standards, has not resulted in a satisfactory level of refugee protection. The claim is, on the contrary, that it has resulted in an uneven sharing of responsibilities for asylum seekers between Member States and an overall deterioration in the guarantees offundamental rights in EU asylum-granting procedures. The article analyses the Dublin II Regulation (establishing the criteria and mechanisms for determining the Member State responsible for examining asylum applications), which by failing to provide an effective mechanism for responsibility allocation has made the entire asylum system in the European Union dysfunctional and of questionable conformity with the Geneva Convention of 1951 and other international standards of protection. The final part of the article examines the new Commission proposal for amendments and improvements to the current Regulation and shows how the Union has once again missed the chance to create a more efficient and balanced responsibility-sharing system which would consequently provide better protection to asylum seekers and thus better fulfill the objectives of the Geneva Convention.
\end{abstract}

\section{Introduction: towards a better concept of refugee protection?}

The protection of refugees and asylum seekers has been an international and humanitarian responsibility of European countries since the early 1950s and the introduction of the legally-binding Geneva Convention Relating to the Status of Refugees of 1951. 'Any human being having a well-founded fear of being persecuted, in his country of nationality or residence, for reasons of race, religion, nationality, membership of a particular social group or political opinion, ${ }^{2}$ has a right under the Convention to be granted international protection in the signatory states as

\footnotetext{
University of Zagreb, Faculty of Law, final year student.

1 UN General Assembly, 'Convention Relating to the Status of Refugees' (28 July 1951) UN, Treaty Series vol 189, 137.

2 UNGA (n 1) Article 1A(2).
} 
well as other corollary rights evolving from their status. Furthermore, their protection is also guaranteed under the basic principle of non-refoulement inherent in Article $3^{3}$ of the European Convention of Human Rights. ${ }^{4}$

The starting position of members (and future members) of the European Union was complete independence in defining the terms and scope of their individual asylum policies. Matters of asylum were, together with immigration, classified under the Justice and Home Affairs of the 'Third Pillar', where the Member States had complete jurisdiction and exclusive competences. Any possible interstate matters could only be resolved through inter-governmental co-operation. Over time, the European Community/Union assumed Member States' competences in asylum policy due to the inefficiency of diverse national regulations and practices. One can therefore presume that the final objective of the transfer in competences was an increase in protection of refugees in line with the Geneva Convention. The question arises whether the result has been successful. Has the gradual introduction of EU harmonisation with the assumption of providing better protection really achieved the overall objective of Geneva both in theory and in practice or has the Europeanisation of asylum policy been superficial?

The main thesis of this paper is to demonstrate how this transfer of competences from the Member States to the European Union, although guided by the objective of improving and harmonising the protection of refugees and asylum seekers, has not resulted in a satisfactory level of protection guaranteed by international law. On the contrary, it has resulted in an uneven sharing of responsibilities for asylum seekers between Member States and an overall deterioration of guarantees of fundamental rights in EU asylum-granting procedures. The fact that progress has been made cannot be denied. Asylum policy has been improved and strengthened in many respects. However, is that enough for a humanitarian European Union with a strong respect for fundamental human rights and human dignity? At this point, it is important to mention that the paper will deal mainly with procedural issues of EU asylum policy. Only the most important issues of substantive law will be referred to as a means of demonstrating the realisation of the overall objective of providing protection.

The first section will deal with the development of the Union's competences in asylum policy. A historical overview, with special reference to the Union's strategies, objectives, programmes and legislative amend-

\footnotetext{
3 See Soering $v$ United Kingdom (1989) 11 EHRR 439.

4 Council of Europe, 'European Convention for the Protection of Human Rights and Fundamental Freedoms' 4 November 1950 ETS 5.
} 
ments, is necessary in order to truly comprehend the disparities between the level of protection the Union was trying to achieve and the level achieved in reality. The developments will be critically assessed and the main issues and problems, which will be the subject of the following sections, will be pointed out.

The second section will deal in more detail with issues arising from the transfer of competences to the EU: the uneven burden-sharing responsibilities of the Member States as a corollary of the Dublin system, and the lack of guarantees of fundamental rights of asylum seekers in EU asylum-granting procedures. These two arguments will establish the grounds to ascertain the main claim of the paper. Namely, they will demonstrate how the EU has failed to provide an effective mechanism for determining Member State responsibility for examining asylum claims, and in this way made the entire asylum system in the EU dysfunctional and of questionable conformity with international standards of refugee protection.

The third section will examine the new proposal for improvements of the responsibility-sharing mechanism (the so-called Dublin III proposal) and demonstrate how the Union once again missed the chance to create a more efficient and balanced responsibility-sharing system which would provide better protection to asylum seekers and thus better fulfil the objective of the Geneva Convention.

The final section will give an overview of the paper's main claims and arguments, summarise the Union's current achievements in asylum policy and make concluding remarks about its deficiencies.

\section{From a national, via an international level, towards a supranational level of refugee protection}

For reasons of comprehending and simplifying the complexity of the issues arising from the switch of competences in European Union asylum (and refugee) policy, this section will try to explain the merits of its development at the national and international level, as well as the process of its communitarisation and harmonisation at a supranational level.

\subsection{National and international asylum policies}

In the context of European Union law, asylum policy was once perceived as a matter of strictly national interest for Member States and had a politically sensitive tone closely connected to national sovereignty. ${ }^{5} \mathrm{As}$

5 C Kaunert and S Léonard, 'The EU Asylum Policy: Towards a Common Area of Protection and Solidarity?' in S Wolff, F Goudappel and J de Zwaan (eds), Freedom, Security and Justice After Lisbon and Stockholm (TMC Asser Press 2011) 80. 
part of a wider context of immigration and the external policies of the Member States, its classification under the Third Pillar of the European Community made asylum policy subject to purely internal arrangement and possible intergovernmental co-operation in interstate matters. National actors were understandably careful in processing asylum applications and dealing with asylum and refugee migration issues in general, considering the over-burdening effect ${ }^{6}$ that an 'undercontrolled' inflow of asylum seekers and refugees might have in an internal context, and bearing in mind the social situation in Europe in the second half of the $20^{\text {th }}$ century.Furthermore, the European Community in its beginnings as an economic entity had no jurisdiction or capacity to deal with the 'Justice and Home Affairs' issues of what later became the Third Pillar or to control them. The overall result was a 'securitarian approach'7 by European states towards asylum policy. The real playground interconnecting these scattered and securitarian national systems until the 1990s was the international arena.

The international protection of refugees developed as a corollary of World War II within the framework of the United Nations legislature. On 14 December 1950, the General Assembly adopted a resolution constituting the office of the United Nations High Commissioner for Refugees. ${ }^{8}$ Only one year later, in 1951, the most important international instrument of refugee law was passed: the Geneva Convention Relating to the Status of Refugees. ${ }^{9}$ The Convention grants international protection to all those qualified as refugees ${ }^{10}$ by forbidding the signatory states to

impose penalties on refugees who, coming directly from a territory where their life or freedom was threatened, enter or are present in their territory without authorization, ${ }^{11}$ to expel a refugee lawfully in their territory save on grounds of national security or public order, ${ }^{12}$ or to expel or return a refugee in any manner whatsoever to the frontiers of territories where his life or freedom would be threatened on account of his race, religion, nationality, membership of a particular social group or political opinion. ${ }^{13}$

\footnotetext{
6 R Byrne, G Noll and J Vedsted-Hansen, 'Understanding Refugee Law in an Enlarged European Union' (2004) 15(2) European Journal of International Law 355-379.

7 SS Juss, 'The Decline and Decay of European Refugee Policy' (2005) 25(4) OJLS 749, 751 .

8 UNGA, Statute of the Office of the United Nations High Commissioner for Refugees, Res 428(V) (14 December 1950).

9 UNGA (n 1).

10 UNGA (n 1) Article 1A(2).

11 UNGA (n 1) Article 31.

12 UNGA (n 1) Article 32.

13 See UNGA (n 1) Article 33 on the principle of non-refoulement.
} 
Another instrument to be noted at the beginning is the $1967 \mathrm{New}$ York Protocol ${ }^{14}$ to the Geneva Convention, which expanded the territorial scope of the Convention's application, from its initial limitation to Western Europe, to the rest of Europe and the world. Furthermore, the Protocol expanded the application of the Convention: the subjects of the Convention were henceforth not limited to persons falling within the strict definition of a pre-1951 'war' refugee.

The Geneva Convention not only became the cornerstone of international refugee protection ${ }^{15}$ very quickly after its adoption, but also increased in importance over time, as will be seen in this paper. All the Member States, in their increasing numbers, are signatories to the Convention. However, the problems of states' application of the Convention became apparent very quickly, doubtlessly induced by internationality, and lack of effective enforcement and systems of control over states' conduct. The result was a mass of different interpretations of the main definitions and objectives of the Geneva Convention. The background issues cannot be disregarded: the economic crisis of the 1970s; the social and technical developments of the $20^{\text {th }}$ century, such as the advancement and greater accessibility of travel options; the rise and fall of the Iron Curtain; the conflicts in the former Yugoslavia, etc. All these facts, combined with the various interpretations of the Geneva Convention and the even more various forms of application of asylum policies, ultimately brought about an "almost total paralysis' ${ }^{16}$ in national asylum systems by the beginning of the 1990s. No higher number of asylum applications was ever recorded. Purely internal and protectionist national policies on asylum and protecting refugees were destined to fail given the lack of protection guaranteed by the Geneva Convention. This is the point where the European Community used its opportunity to become the main actor in refugee protection. The gradual transfer of competences to the EU opened the door for the Europeanisation and harmonisation of asylum policy.

\subsection{Development of asylum policy in the EU}

\subsubsection{The early phase}

One of the first initiatives the European Community made was the reference to refugee issues in the Schengen Convention of $1990,{ }^{17}$ but

\footnotetext{
14 UNGA, 'Protocol relating to the Status of Refugees' (31 January 1967) UNTS vol 606, 267.

15 C Kaunert, 'Liberty versus Security? EU Asylum Policy and the European Commission' (2009) 5(2) Journal of Contemporary European Research 148, 150.

16 N El-Enany and E Thielemann, 'The Impact of EU Asylum Policy on National Asylum Regimes' in Wolff, Goudappel and de Zwaan (n 5) 101.

17 European Union, 'Convention Implementing the Schengen Agreement of 14 June 1985 between the Governments of the States of the Benelux Economic Union, the Federal Re-
} 
only in the context of the removal of remaining security barriers to the free movement of persons. The allocation of responsibilities for asylum seekers was the main issue. The Dublin Convention of $1990^{18}$ superseded the seventh Schengen chapter on this issue, and thus became the first instrument of the European Community actually dealing with asylum policy and creating an 'effective system' for allocation of the responsibilities of Member States in examining claims for refugee status. The underlying principle was the consideration of the individual application in only one Member State, the one of first entry. Two main problems arose from these very early provisions. The state-of-first-entry concept abolished any opportunity for other assessments of the individual asylum seeker's situation by any other Member State, irrespective of the possible interconnections he/she may have had with that State. Furthermore, the initial objective of burden-sharing between Member States potentially became an excuse for burden shifting. At this point, it should be noted that this principle has been one of the most problematic ones when considering EU asylum policy up to the present, and thus will be examined in more detail in the following section of the paper.

The starting point of the harmonisation of asylum policy was the entry into force of the Amsterdam Treaty on 1 May 1999. ${ }^{19}$ By granting new legislative powers to EU institutions, more precisely by allowing them to use the legislative tools of Article 251 TEC, such as regulations and directives, asylum policy was shifted from the Third to the First Pillar. The previous Maastricht Treaty had placed asylum policy into a category of 'matters of common interest' in Justice and Home Affairs, still safeguarding the intergovernmental approach. Amsterdam, however, showed that the Community was ready to take a step forward and announce a restriction on Member States' competences over a certain period of time. Article 73k stated that

[the] Council, acting in accordance with the procedure referred to in Article 73o, shall, within a period of five years after the entry into force of the Treaty of Amsterdam, adopt:

1) measures on asylum, in accordance with the Geneva Convention of 28 July 1951 and the Protocol of 31 January 1967 relating to the

\footnotetext{
public of Germany and the French Republic, on the Gradual Abolition of Checks at their Common Borders' (Schengen Implementation Agreement) 19 June 1990.

18 European Union, 'Convention Determining the State Responsible for Examining Applications for Asylum Lodged in one of the Member States of the European Communities' (Dublin Convention) OJC 254, 19 August 1997, 1-12.

19 Treaty of Amsterdam Amending the Treaty of the European Union, the Treaties Establishing the European Communities and Certain Related Acts, 2 October 1997.
} 
status of refugees and other relevant treaties, within the following areas:

(a) criteria and mechanisms for determining which Member State is responsible for considering an application for asylum submitted by a national of a third country in one of the Member States,

(b) minimum standards on the reception of asylum seekers in Member States,

(c) minimum standards with respect to the qualification of nationals of third countries as refugees,

(d) minimum standards on procedures in Member States for granting or withdrawing refugee status.

In an analysis of the Article in question, several issues have to be addressed.

Firstly, the Article formed four areas of asylum policy that were in need of harmonisation: the responsibility of a Member State to consider an application for asylum submitted by a national of a third country in one of the Member States; the standards on the reception of asylum seekers within Community territory; the qualification of third-country nationals as refugees; and standards on procedures for granting or withdrawing refugee status. The unification and upgrade of standards in these four areas has remained the leading objective of the Union in the protection of asylum seekers up to the present.

Secondly, the European Community showed a clear intention of taking charge of the situation but carefully chose its words so as not to cause an opposite effect within the national policies of each Member State. The 'minimum standards' phase announced a first step in the harmonisation process: the creation of a common European minimum level of protection that every Member State would have to provide to asylum seekers and refugees.

Thirdly, compliance with the Geneva Convention, its Protocol and other relevant international instruments of protection was clearly emphasised. Accordingly, it can be argued that the level of protection the Union was aiming to achieve from the beginning of its asylum policy was the one guaranteed by the Geneva Convention.

Fourthly, upgrading of the institutional framework was announced. During the five-year transitional period, the legislative procedure, according to Article 73o, was still to be based on the unanimous decisionmaking of the Council, but only after consulting the European Parliament. The unanimity condition, not that different from the intergovernmental level of the Third Pillar, was not yet disregarded. Furthermore, 
the Commission's position was strengthened in the sense that it gained the right of legislative initiative. However, that right was still not an exclusive one, since the Member States also had, at least in the transitional period, the same right of initiative as before the amendments.

The main achievement of the Amsterdam amendments was the transfer of asylum policy to the First Pillar and its institutional and legislative frameworks. However, the Member States were still left with a wide range of powers and remained the main actors in the asylum policy area. Any legislative act could still not pass if even one Member State did not give its approval. Furthermore, the focus was only on the creation of 'minimum standards'. A conclusion can be drawn from David O'Keeffe's observation that 'the provisions on asylum are largely concerned with the setting of minimum standards or are procedural rather than focused on high-level common substantive standards'. ${ }^{20}$

\subsubsection{The first phase of the Common European Asylum Policy (CEAS)}

A new initiative of moving forward in the harmonisation process was produced only a couple of months after the adoption of the Amsterdam Treaty, at the Tampere Meeting of the European Council of October 1999. ${ }^{21}$ While the Amsterdam Treaty did not go beyond the intention of defining 'minimum standards' of terms and procedural conditions in asylum policy, the Tampere Conclusions of the Presidency of the European Council showed a clear intention of creating a 'common policy' at the European level. The Common European Asylum Policy (CEAS) was established with recognition of the 'absolute respect of the right to seek asylum' and 'based on the full and inclusive application of the Geneva Convention'. ${ }^{22}$ The so-called first phase of the CEAS began, and it was announced that in the longer term, Community rules should lead to a common asylum procedure and a uniform status for those who are granted asylum valid throughout the Union'. ${ }^{23}$ The CEAS represents the main idea and programme of the asylum policy of the European Community/Union. Its development will be charted throughout the rest of this section.

20 D O'Keeffe, 'Can the Leopard Change its Spots? Visas, Immigration and Asylum: Following Amsterdam', in D O'Keeffe and P Twomey, Legal Issues of the Amsterdam Treaty (Hart Publishing 1999) 272.

${ }^{21}$ European Council, 'Tampere European Council, 15 and 16 October 1999, Presidency Conclusions' <http://www.europarl.europa.eu/summits/tam_en.htm> accessed 9 July 2012.

22 European Council (n 21) paras 13-15; G Gilbert, 'Is Europe Living up to its Obligations to Refugees?' (2004) 15(5) The European Journal of International Law 963, 970.

23 European Council (n 21) para 15. 
At this point, it is important to emphasise that the Treaty of Nice ${ }^{24}$ took a further step away from the intergovernmental dimension of asylum policy by introducing the possibility of decision-making (at the European level) based on qualified majority voting in the Council and the concept of co-decision-making together with the Parliament. The possibility of removing the unanimity condition was also introduced. A new clause was added to Article 67(5) TEC which made qualified majority voting conditional on the prior and unanimous decision of the Council itself. The final decision upon the switch to ordinary legislative procedure (though not using those exact words in the Treaty) was not made until the end of 2004. The Commission's position, as seen from its Assessment of the Tampere Programme, is that 'the original ambition [the abovementioned step forward in the competences switch] was limited by institutional constraints, and sometimes also by a lack of sufficient political consensus'. ${ }^{25}$ Only in 2005 was qualified majority voting and the co-decision procedure introduced into the Community's asylum policy. However, two legislative acts, discussed in more detail below, were brought under the unanimity condition and the use of the sovereign powers of each Member State, which was in accordance with the five-year transitional period idea introduced in Amsterdam.

Under the guidelines of the Tampere programme, a number of legislative acts were introduced in the Community legislature in the first stage of the development of the CEAS.

The Directive laying down minimum standards for reception of asylum seekers of $2003^{26}$ introduced a number of standards that Member States had to comply with when dealing with asylum seekers, such as providing them with the right of residence, employment, education, healthcare and sufficient information about their status and rights.

The Regulation establishing the criteria and mechanisms for determining the Member State responsible for examining an asylum application (known as Dublin II) was passed in 2003. ${ }^{27}$ The primary objective of this Regulation, succeeding the previous Dublin Convention, was stating that an individual asylum seeker had access to only one asylum procedure in one Member State, which would thereafter be valid throughout

\footnotetext{
${ }_{24}$ Treaty of Nice amending the Treaty on European Union, the Treaties Establishing the European Communities and Certain Related Acts, 2001/C 80/01, 11 December 2000.

25 Juss (n 7) 763.

26 Council Directive 2003/9/EC of 27 January 2003 laying down minimum standards for the reception of asylum seekers [2003] OJ L31/18.

27 Council Regulation (EC) No 343/2003 of 18 February 2003 establishing the criteria and mechanisms for determining the Member State responsible for examining an asylum application lodged in one of the Member States by a third-country national [2003] OJ L50/1.
} 
Community territory. The concept of burden-sharing between Member States has not changed a lot and is not much different from the one in the Dublin Convention. Providing that there is no need for reunification of the closest family members, with special regard towards minors, the concept of the Member State of first entry into Community territory conducting the asylum procedure is still predominant. The problems arising from this concept will be the subject of further scrutiny in the following section.

The Directive on minimum standards for qualification as refugees of $2004^{28}$ defined for the first time in European Union law the necessary qualifications for a third-country national or stateless person to be regarded as a refugee, and the content of the protection granted to such a person. According to Article $2 \mathrm{c}$ of the Directive, a refugee is a person

who, owing to a well-founded fear of being persecuted for reasons of race, religion, nationality, political opinion or membership of a particular social group, is outside the country of nationality [or the country of former habitual residence for stateless persons] and is unable or, owing to such fear, is unwilling to avail himself or herself of the protection of that country. ${ }^{29}$

The definition in question is the complete implementation in European law of the criteria of the Geneva Convention. However, the Directive introduced another form of protection previously unknown in the international dimension of the protection of refugees: subsidiary protection. A person eligible for subsidiary protection is defined in Article $2 \mathrm{e}$ of the Directive as a "person who does not qualify as a refugee but, if returned to his or her country of origin (or country of former habitual residence), would face a real risk of suffering serious harm. ${ }^{30}$ At this point, one might argue that protection at the European level had reached an even higher level in the protection of refugees, not only by defining the term of refugee and the rights corresponding to such status, by that way harmonising it with the Geneva Convention, but also by providing certain rights to persons who may not satisfy the conditions for refugees but who are nevertheless in need of some kind of international protection. Protection of the same scope could have been provided through application of Article 3 ECHR and the principle of non-refoulement, but the subsidiary protection mechanism gave it a more easily enforceable, insti-

28 Council Directive 2004/83/EC of 29 April 2004 on minimum standards for the qualification and status of third country nationals or stateless persons as refugees or as persons who otherwise need international protection and the content of the protection granted [2004] OJ L304/12.

29 Council Directive 2004/83/EC (n 28) Article 2c.

30 Council Directive 2004/83/EC (n 28) Article 2e. 
tutional significance. Furthermore, the Directive also made it possible to grant protection against non-state actors of persecution and/or serious harm. One cannot deny that the European Community had taken a step forward in the protection of basic human rights, in terms of its content maybe even greater than the Geneva Convention itself, when considering the subsidiary protection issue. The Directive was considered a success in the eyes of some NGOs and asylum experts. It was even referred to as 'a remarkable development'. ${ }^{31}$ However, is the theoretical level of protection sufficient to merit such high compliments while the practical and procedural dimensions still suffer from a lack of efficient means to provide actual protection to people in need of it in the basic context of them as human beings with fundamental rights? I will return to this issue in the following section.

The Directive on minimum standards on procedures in Member States for granting or withdrawing refugee status of $2005^{32}$ codified the basic procedural rights of refugees, such as the right of access to the asylum procedure, legal assistance and interpretation, the right to an interview, the right to remain in a Member State during the examination of the application, the conditions of detention and the right to appeal. Furthermore, the Directive introduced three concepts as grounds for dismissal of an asylum application or for narrowing of the Community's responsibility: the concept of 'first country of asylum', where the asylum applicant already has the status of refugee in a non-Member State and thus does not need such status within Community territory; the existence of a 'safe country of origin' as grounds for the consideration of a group of applications in an accelerated procedure, all deriving from nationals of the same listed country; and a 'safe third country' as grounds for the possible transfer of the asylum procedure to countries acceding to the EU. ${ }^{33}$ These controversial concepts have often been criticised ${ }^{34}$ as undermining the main objective of the Tampere programme and the main idea behind the CEAS by becoming an excuse for avoidance of Member States' main responsibilities under the Geneva Convention and EU law: the obligation to provide international protection to persons in need of such protection. Furthermore, the Directive has also been criticised for not giving strong enough guarantees that an individual application will actually be reviewed in accordance with the Geneva Convention, especially when combined with the Dublin II Regulation. Without entering at this point into a deeper discussion of these is-

\footnotetext{
31 H Storey, 'EU Refugee Qualification Directive: A Brave New World?' (2008) 20(1) International Journal of Refugee Law 1, 5.

32 Council Directive 2005/85/EC of 1 December 2005 on minimum standards on procedures in Member States for granting and withdrawing refugee status [2005] OJ L326/13.

33 See Articles 26, 27 and 31 of Council Directive 2005/85/EC (n 32).

34 Kaunert (n 15) 155.
} 
sues, one must also bear in mind that the level of procedural protection has, on legislative grounds and in practice, been raised in some Member States $^{35}$ by the implementation of this Directive. In this sense, a directive creating certain higher standards could never be described as a possible breach of Member States' obligations under international law. However, could an improvement in procedural standards in a handful of Member States really justify the overall lack of procedural guarantees of the entire asylum policy of the EU?

\subsubsection{The second phase of the CEAS}

The above-mentioned Directives and Regulation harmonised EU asylum policy at a 'minimum standards' level and thus completed the objective of the first phase of the CEAS and laid the foundations for future development. The second phase started at this point and established the need to go beyond the 'minimum' in achieving a 'common policy' in the CEAS. The Hague Programme of the European Council of $2004^{36}$ formulated the plan of development for the next five years:

The aims of the CEAS in its second phase will be the establishment of a common asylum procedure and a uniform status for those who are granted asylum or subsidiary protection. It will be based on the full and inclusive application of the Geneva Convention on Refugees and other relevant Treaties, and be built on a thorough and complete evaluation of the legal instruments that have been adopted in the first phase. ${ }^{37}$

Not many legislative acts have so far been adopted under the Hague guidelines. However, an act that could be considered a real institutional success of this period is the Regulation for establishing a European Asylum Support Office (EASO) of 2010. ${ }^{38}$ The Regulation was drafted with the aim of creating institutional structures to support Member States in providing asylum services and for their mutual co-operation. Development in other areas remained fairly slow. Even the final deadline of the creation of the CEAS under the Hague Programme was postponed for two years: the new deadline being 2012. The recast versions of the Directives and the Regulation were, however, proposed by the Commission in 2008 and 2009.

\footnotetext{
35 Eg in Portugal and Spain.

36 European Council, 'Brussels European Council, 4-5 November 2004, Presidency Conclusions' 14292/1/04 Brussels 8 December 2004 <http://www.consilium.europa.eu/uedocs/cms_data/docs/pressdata/en/ec/82534.pdf> accessed 9 July 2012.

37 European Council (n 36) 17 (emphasis added).

38 Regulation(EU) No 439/2010 of the European Parliament and of the Council of 19 May 2010 establishing a European Asylum Support Office [2010] OJ L132/11.
} 
The Hague Programme of 2004 also announced the need for a final decision on qualified majority voting by the Council. This decision, as was stated earlier, was brought by the Council the following year. Although the difficult-to-achieve unanimity was no longer supposed to be an issue, the Council could not find common ground for the final decisions on the recast versions for a very long time. Only one of the four proposals was finally passed in 2011: the Directive on standards for the qualification of third-country nationals or stateless persons as beneficiaries of international protection, for a uniform status for refugees or for persons eligible for subsidiary protection, and for the content of the protection granted, ${ }^{39}$ which Member States have to transpose into their national legislation by 21 December $2013 .{ }^{40}$ The other three areas of EU asylum policy still remain the subject of discussion and amendments: the Amended proposal for a Directive laying down standards for the reception of asylum seekers of 2008; Proposal for a Regulation establishing the criteria and mechanisms for determining the Member State responsible for examining an application of $2008^{41}$ (so-called Dublin III); and the Amended proposal for a Directive on common procedures for granting and withdrawing international protection status of 2009. ${ }^{42}$ As can be seen from the wording of the new legislation and proposals, these second-phase instruments of the CEAS aim to raise the level of protection by abolishing the usage of terms such as 'minimum' and raising them to the level of 'uniform' or 'common'.

The new Qualifications Directive has brought certain improvements in defining people in need of protection and the content of such protection. The mere change in the wording of its title, although a big policy step, is not the only improvement in the new directive. Some of the obvious improvements are the wider definition of family members of the refugee for whom protection is also provided, stricter conditions on protection in the country of origin if a person is to be sent back, stricter conditions on cessation of refugee or subsidiary protection status, "persecution' (against which the protection is to be granted) now also includes the

\footnotetext{
39 Directive 2011/95/EU of the European Parliament and of the Council of 13 December 2011 on standards for the qualification of third-country nationals or stateless persons as beneficiaries of international protection, for a uniform status for refugees or for persons eligible for subsidiary protection, and for the content of the protection granted (recast) [2011] OJ L337/9.

40 The UK, Ireland and Denmark have opted out.

${ }^{41}$ Commission, 'Proposal for a Regulation of the European Parliament and of the Council establishing the criteria and mechanisms for determining the Member State responsible for examining an application for international protection lodged in one of the Member States by a third-country national or a stateless person' (Recast) COM (2008) 820 final.

42 Commission, 'Amended proposal for a Directive of the European Parliament and of the Council on common procedures for granting and withdrawing international protection status' (recast) COM (2011) 319 final.
} 
failure of the relevant authorities to act in providing protection, etc. It will be interesting to see how the other amended versions of the legislative acts will contribute to the creation of the CEAS, especially since the deadline for the final framing of the common policy was supposed to be the end of 2012. Since negotiations are still in progress, it would not be appropriate to refer to all of their downsides at this point.

\subsubsection{The Lisbon Treaty and the third phase of the CEAS}

The Treaty of Lisbon, ${ }^{43}$ which came into force on 1 December 2009, did not bring any revolutionary developments to asylum policy. However, the concept of the CEAS was constitutionalised through the confirmation of the EU competences in developing asylum policy.

Article $78 \mathrm{TFEU}^{44}$ provides that

1. The Union shall develop a common policy on asylum, subsidiary protection and temporary protection with a view to offering appropriate status to any third-country national requiring international protection and ensuring compliance with the principle of non-refoulement. This policy must be in accordance with the Geneva Convention of 28 July 1951 and the Protocol of 31 January 1967 relating to the status of refugees, and other relevant treaties.

2. For the purposes of paragraph 1, the European Parliament and the Council, acting in accordance with the ordinary legislative procedure, shall adopt measures for a common European asylum system comprising:

(a) a uniform status of asylum for nationals of third countries, valid throughout the Union;

(b) a uniform status of subsidiary protection for nationals of third countries who, without obtaining European asylum, are in need of international protection;

(c) a common system of temporary protection for displaced persons in the event of a massive inflow;

(d) common procedures for the granting and withdrawing of uniform asylum or subsidiary protection status;

(e) criteria and mechanisms for determining which Member State is responsible for considering an application for asylum or subsidiary protection;

43 Consolidated versions of the Treaty on European Union and the Treaty on the Functioning of the European Union, 2010/C 83/01, 30 March 2010.

44 TEC ex Article 63a. 
(f) standards concerning the conditions for the reception of applicants for asylum or subsidiary protection;

(g) partnership and cooperation with third countries for the purpose of managing inflows of people applying for asylum or subsidiary or temporary protection.

First of all, the Treaty provision finally incorporated at a constitutional level the competences of the EU in developing asylum policy, although they had been the objective of previous legal instruments and the Tampere and Hague Programmes. However, the previous Treaties had only referred to the Community as being obliged to develop 'measures on asylum. ${ }^{45}$ Lisbon finally took the leap of introducing the Common European Asylum System into the constitutional level of the Union's legal order. The choice of wording such as 'uniform status' of asylum and subsidiary protection, a 'common' system of temporary protection and 'common' procedures, also indicates the switch of competences in asylum policy, going beyond the previously established minimum standards. What is also important to mention at this point is that by referring to the 'status of asylum' instead of the previous 'qualification as refugees', EU policy (finally) completely reflected the title and content of the Geneva Convention. ${ }^{46}$

Secondly, at the institutional level, Lisbon stated that all measures on asylum policy will be adopted by the Parliament and the Council as part of the ordinary legislative procedure, as laid down in Article 294 TFEU. The previous Treaty provisions prescribed co-decision-making with a qualified majority vote in the Council. Although the difference between these two types of procedure is not that different in practice, this innovation was important from the viewpoint of the Parliament. Its joint decision-making power and power to influence asylum policy could no longer be subject to any debate and was now guaranteed under the highest legal act of the Union.

Another important institutional change of the Lisbon Treaty is the strengthening of the powers of the Court of Justice of the European Union. While its previous jurisdiction had been strictly limited, the Court was now given preliminary reference jurisdiction in the entire Area of Freedom, Security and Justice, including matters of asylum. This opened the opportunity for a judicial shaping of asylum policy and Union competences based on a number of cases that are, and will be coming, in front of the Court.

\footnotetext{
45 Article 63 TEC.

46 Since no deadline was set in the Treaty itself for a final achievement of the common system, as it had been in previous practice, it cannot be stated when the final objective of a common policy will be fulfilled.
} 
There is no doubt that the institutional role of the EU has increased and that Lisbon switched the balance of the (shared) competences in asylum policy from the Member States to the EU. ${ }^{47}$ However, the development of strategic guidelines for the legislative and operational planning of asylum policy was still left to the European Council under Article 68 TFEU. Once aware of this fact, it is interesting to question to what extent Member States have really renounced their potential to influence the development of the 'common' policy.

Nevertheless, one cannot deny that the EU has been given full competence under the Lisbon Treaty to harmonise asylum policy in its entirety. How the newly adopted legislation and proposals currently under negotiation will in reality lead to a complete 'common system' will surely be subject to much debate. Will the mere change in the wording of the titles and terms, indicating a step towards this common policy, create such a policy in reality and achieve the protection granted under the Geneva Convention? Or will the deeply needed ameliorations stay marginalised due to the difficulty of negotiations and finding a satisfactory conclusion?

Another issue arising from the Lisbon amendments to the European legal order is the introduction of the Charter of Fundamental Rights of the European Union. ${ }^{48}$ The Charter, having the same legal value as the Treaties, is extremely important to asylum policy from a protection of human rights viewpoint. It guarantees the right to asylum in Article 18, again emphasising respect for the 1951 Geneva Convention and its 1967 Protocol. The right of a person to seek and, under certain circumstances, be granted asylum has become enforceable under Union law, and a new human rights dimension has been introduced into the European legal order. All the legislative and practical steps of the Union's institutions and the Member States will no longer be subject only to compliance with the international concept of refugee protection, binding on Member States as signatories to the Geneva Convention. They will also be subject to basic fundamental human rights protection from within the Union's legal order itself.

The latest 'Stockholm' programme on the Area of Freedom, Security and Justice, and asylum policy was formed by the European Council in December 2009 for the five-year period 2010-2015. ${ }^{49}$ The Programme

\footnotetext{
47 Article 4.2 (j) TFEU.

48 Charter of Fundamental Rights of the European Union, 2010/C 83/02, 30 March 2010 .

49 Council of the European Union, The Stockholm Programme: An open and secure Europe serving and protecting the citizen', 17024/09 Brussels 2 December $2009<\mathrm{http}$ ://register. consilium.europa.eu/pdf/en/09/st17/st17024.en09.pdf> accessed 9 July 2012.
} 
states the need to establish a "common area of protection and solidarity based on a common asylum procedure and a uniform status for those granted international protection ${ }^{50}$ by 2012 , aiming for the recast versions of the asylum directives and regulation(s) to be passed.

An important issue stressed by the Programme is fostering practical co-operation between Member States, guided by the newly established European Asylum Support Office, and balanced and effective burdensharing (the burden of conducting asylum procedures being the responsibility of the Member States). The above-mentioned objectives clearly indicate that the Union is aware of the downsides of EU asylum policy that exist in practice. The current diversity of Member States' responsibilities and the level of protection they offer is the most problematic issue in this area. This 'second level of competences in the asylum policy' (the practical one between the Member States themselves) ${ }^{51}$ is described as follows:

Effective solidarity with the Member States facing particular pressures should be promoted. This should be achieved through a broad and balanced approach. Mechanisms for the voluntary and coordinated sharing of responsibility between the Member States should therefore be further analyzed and developed. ${ }^{52}$

It can be seen, from the above-mentioned wording of the Programme, that the initiative of the Union in solving the problems cannot be seen as very assertive. Phrases such as the "voluntary development of the responsibility sharing' and the 'promotion of solidarity' indicate a lack of intention to regulate the issue on a legally binding and compulsory basis due to the obviously strong resistance of Member States to any final system of burden-sharing other than the current ineffective one set out in Dublin II.

A positive aspect of the Union's objectives in reaching a common asylum policy, as seen from the Programme, was asserting the need to maintain the long-term sustainability of the asylum system by basing the development of the CEAS on a full and inclusive application of the Geneva Convention. ${ }^{53}$ The human rights dimension of the Union's asylum policy had finally received well-deserved attention. The Programme indicated the ambition of the Union to seek accession to the Geneva Convention and its 1967 Protocol. ${ }^{54}$

50 Council of the European Union (n 49) 69.

51 In comparison with the 'first level of competences', the legislative one of the Union.

52 Council of the European Union (n 49) 71.

53 Council of the European Union (n 49) 69.

54 Subject to a report from the Commission on the legal and practical consequences. 


\section{The inefficiency of EU asylum policy: the problems of allocation of responsibility between Member States under the Dublin system}

The transfer of competences in asylum policy to the European Union has been guided by the objective of establishing a Common European Asylum System, as defined by the Tampere programme, and in that way ensuring that appropriate protection is granted to all persons in need of it, as required by the Geneva Convention and other relevant international treaties on the protection of refugees and asylum seekers. The means of granting substantive protection developed within the European legal order, discussed in the previous section, is through allocating the responsibility for its enforcement to the real actors of asylum policy: the Member States.

\subsection{The Dublin system in theory}

The Dublin Regulation (Dublin II), passed in 2003, established the criteria for determining which Member State is responsible for examining a lodged asylum application. This so-called Dublin system is founded on the principle that only one Member State should be responsible for such an examination and a number of criteria are established in the Regulation in order to determine such responsibility. As stated in the previous section, the underlying principle is that the responsible Member State is the one where the asylum seeker first entered the Union's territory, save for certain very limited reasons of reunification of immediate family members (spouses and children who are minors) and the issuance of a valid residence permit in a particular Member State..$^{55}$ Only if the illegal crossing of the Union's borders has not been noticed and processed by the relevant authorities in the relevant border Member State can an asylum seeker have their application examined in the Member State where they actually lodged it and wanted to lodge it. However, the percentage of such cases in practice is so low that this rule could be neglected.

In addition, the Regulation also allows for a Member State to take on such a responsibility, even if one does not exist under the Dublin rules, for reasons at its own discretion (the so-called sovereignty clause) ${ }^{56}$ or for humanitarian reasons of family reunification not provided for in the compulsory provisions (the so-called humanitarian clause). ${ }^{57}$ Although the inclusion of such clauses can be seen as a positive aspect of Dublin

\footnotetext{
55 Council Regulation (EC) No 343/2003 (n 27) Chapter 3.

56 Council Regulation (EC) No 343/2003 (n 27) Article 3.2.

57 Council Regulation (EC) No 343/2003 (n 27) Article 15.
} 
II, their application is purely voluntary and differs greatly from one Member State to another.

According to Article 4.5 of the Regulation, if an asylum seeker goes to another Member State and also lodges an application for asylum there, he shall be taken back to the Member State responsible. Asylum seekers, or even persons already granted asylum, do not have the right to move and reside freely throughout Union territory other than in the territory of the State responsible for their protection and asylum status. A corollary of such a system, in which only one Member State is responsible, is a great number of transfers of persons situated in States having no responsibility. The cases of such movements and transfers are in practice frequent. It is no wonder that the issues surrounding them have become a subject of much debate.

\subsection{The inefficiency of the Dublin system in practice}

The main issue arising from the Dublin provisions on the allocation of responsibility for conducting asylum procedures is the practical aspect of its application in the 27 Member States. The Dublin system has, in almost 10 years of its application, ${ }^{58}$ proved to be inefficient in realising the burden-sharing system, as required by the Treaty provisions and as defined under the Tampere programme. The burden-sharing system was conceived as a means of implementing the principles of the 'established' common policy on asylum and providing international protection in accordance with the Member States' international obligations and the Geneva Convention.

By failing to provide an effective mechanism for burden allocation, the Dublin II Regulation has made the entire asylum system in the European Union dysfunctional and of questionable conformity with international standards of protection for asylum seekers and refugees. This claim is supported and affirmed by two main arguments. Firstly, the Dublin system creates uneven burdens on Member States on the borders of the Union, which subsequently results in even greater disparities in the quality of protection provided in already diverse Member States. Secondly, the procedures for transfers, in combination with the overall asylum-granting procedure, by not providing sufficient guarantees bring into question the protection of internationally guaranteed refugee rights, as well as basic human fundamental rights. I will elaborate on these arguments in the following sections.

58 Even more if taking into account the previous Dublin Convention 1990 (applied from 1997), given that the basic principles do not differ. 


\subsubsection{The uneven distribution of responsibilities for asylum claims}

The Dublin allocation of responsibility is based on the incorrect presumption that all Member States provide an equal amount and quality of protection as if a true common policy has already been established. ${ }^{59}$ Although the objective of the CEAS is that the chance of being granted asylum is essentially the same in each and every Member State, practice shows that there are still many divergences in national policies. In some Member States, more than 50\% of asylum applications result in success, while in others the percentage is even lower than $1 \% .{ }^{60}$ Although the grounds for harmonisation exist in the legislative context of the Union, Member States still have differing approaches to the implementation of the standards arising from the previously mentioned directives. Furthermore, there is always the possibility of inadequate transposition or simply inadequate practice. As concluded by the UNHCR, 'greater harmonization and a notable improvement in standards in some Member States continue to be needed before the basic assumption of equal access to protection in the EU can be validated'. ${ }^{61}$

Combining this incorrect assumption with the allocation of responsibility based on the State-of-first-entry concept results in a malfunctioning of the entire system. In practice, the majority of the burden is shifted onto the southern and eastern Member States on the borders of the Union, States which are often least able to handle this kind of pressure in terms of both finances and resources. In other words, geographical position becomes the defining principle, while the ability to handle the inflow of asylum seekers becomes irrelevant. Not only are these Member States on the periphery faced with a greater number of entries

\footnotetext{
59 United Nations High Commissioner for Refugees, 'UNHCR's Response to the European Commission's Green Paper on the Future Common European Asylum System' (September 2007) 38: 'the Dublin system is predicated on the assumption that the asylum laws and practices of the participating States utilize common standards and produce comparable results', while '[i]n reality, asylum legislation and practice still vary widely from country to country' <http://www.unhcr.org/refworld/docid/46e159f82.html> accessed 9 July 2012.

60 European Council on Refugees and Exiles, 'The Dublin Regulation: Twenty Voices: Twenty Reasons for Change' (March 2007) 1 <http://www.ecre.org/topics/areas-of-work/ protection-in-europe/136.html> accessed 9 July 2012.

61 United Nations High Commissioner for Refugees, 'UNHCR comments on the European Commission's Proposal for a recast of the Regulation of the European Parliament and of the Council establishing the criteria and mechanisms for determining the Member State responsible for examining an application for international protection lodged in one of the Member States by a third country national or a stateless person ('Dublin II') (COM (2008) 820, 3 December 2008) and the European Commission's Proposal for a recast of the Regulation of the European Parliament and of the Council concerning the establishment of 'Eurodac' for the comparison of fingerprints for the effective application of [the Dublin II Regulation] (COM (2008) 825, 3 December 2008)', 18 March 2009, 2 <http://www.unhcr. org/refworld/docid/49c0ca922.html> accessed 9 July 2012.
} 
to the Union through their territory, which makes them primarily responsible for the asylum procedure under the Dublin rules, but they are also faced with an increased number of transfers from other parts of the Union. As a result, they try to reduce their responsibilities by restricting access to and the conditions of the asylum-granting procedure. An obligation to guarantee the right to a fair hearing thus often comes into question. Some Member States, as ascertained in the ECRE's reports, often do not reopen the files of asylum seekers that left the country and were then transferred back as a result of the application of the Dublin rules. Furthermore, some of the claims have never been heard, and some of them suffer serious delays in processing. In this overburdened system, wronged asylum seekers often do not have another choice but to try to move on to other Member States, even though they formally do not have the right to choose. However, they again find themselves trapped in the asylum system circle shifting them from one State to another. The most problematic and debated case of such overburdening with inflows of asylum seekers and their transfers is Greece.

As stated by Steve Peers:

In recent years Greece has systematically failed to observe its obligations as regards the reception conditions, procedural rights and qualification of asylum seekers, as set out in EU law, the European Convention of Human Rights and the Geneva Convention on Refugee Status. ${ }^{62}$

The severity of the situation was described by the UNHCR, after a detailed examination, as follows:

[A]s a result of structural shortcomings in the Greek asylum procedure, asylum-seekers continue to remain effectively in limbo, unable to exercise their rights, for prolonged periods of time... [T] dure does not guarantee a fair evaluation of asylum claims... Finally, essential procedural safeguards are not guaranteed throughout the refugee status determination process to the detriment of asylumseekers who often lack the most basic entitlements, such as interpreters and legal aid. ${ }^{63}$

Given the internal context of the severe economic crisis in Greece, and the wider European context of Member States not effectively co-op-

\footnotetext{
62 S Peers, 'The Revised "Dublin" Rules on Responsibility for Asylum-Seekers: The Council's Failure to Fix a Broken System' (Statewatch April 2012) $3<$ http://www.statewatch. org/analyses/no-173-dublin-III.pdf> accessed 4 July 2012.

63 United Nations High Commissioner for Refugees, 'UNHCR Position on the Return of Asylum-Seekers to Greece under the "Dublin Regulation"' (2008) $6<\mathrm{http}$ ://www.unhcr. org/refworld/docid/4805bde42.html> accessed 9 July 2012.
} 
erating and helping Greece in resolving asylum policy difficulties, but only overburdening it with a huge number of transferees, the system in Greece simply could not function. This could also be seen from the fact that in 2007, only 140 out of 20,692 applicants were actually granted asylum. ${ }^{64}$ The situation became so severe that the UNHCR in 2008 advised other Member States to refrain from returning asylum seekers to Greece under the Dublin Regulation until further notice, calling upon their obligation to ensure access to fair and effective asylum procedures under the Geneva Convention.

The same was advised by the ECRE, as a result of 'the unacceptable conditions for asylum claimants in Greece, the obstacles to accessing a fair determination procedure and the risk of other serious human rights violations'. ${ }^{65}$ Bjarte Vandvik, the Secretary General of the ECRE, clearly emphasised that 'Greece is not a safe place for those in need of protection. ${ }^{66}$

The Council of Europe also called upon Member States to "halt all transfers of asylum seekers back to countries where they face enormous difficulties in gaining access to the asylum procedure and where they do not enjoy basic safeguards such as interpretation and legal aid'. ${ }^{67}$

As a result of these recommendations, a number of Member States, such as Germany, Sweden and Finland, suspended all transfers to Greece. Such a restrictive approach was also confirmed by the European Court of Human Rights in Strasbourg, as well as the Court of Justice of the European Union itself.

In MSS $v$ Belgium and Greece of January $2011,{ }^{68}$ the Court in Strasbourg found both of these countries to be in breach of the European Convention of Human Rights and its principle of non-refoulement, inherent in Article $3,^{69}$ after they had applied the provisions of EU law on asylum policy. The case considered the transfer of an Afghan asylum seeker from Belgium to Greece under the Dublin rules. The degrading circumstances of detention in Greece and the living conditions he was exposed to after

${ }^{64}$ R Goldirova, 'Greece under Fire over Refugee Treatment' (EU Observer 3 April 2008) <http://euobserver.com/22/25910> accessed 9 July 2012.

65 Goldirova (n 64).

66 European Council on Refugees and Exiles, 'Spotlight on Greece: EU Asylum Lottery under Fire' (Press Release 3 April 2008) 1 <www.ecre.org/component/downloads/downloads / 116.html> accessed 4 July 2012.

67 Council of Europe, Office of the Commissioner for Human Rights, 'The "Dublin Regulation" Undermines Refugee Rights' (Press Release 22 September 2010) 1. <https://wcd.coe. int/ViewDoc.jsp?id=1671357\&Site=DC > accessed 9 July 2012.

68 Case MSS v Belgium and Greece App no 30696/09 (ECtHR, 21 January 2011).

69 Soering (n 3). 
the asylum procedure was conducted (living on the street) amounted to a breach of Article 3 ECHR: any expulsion to a country where there is a 'real risk of being subjected to torture or inhuman or degrading treatment or punishment', ${ }^{70}$ even to an 'intermediary country', ${ }^{71}$ is forbidden. By extraditing the asylum seeker to Greece, exposing him to such conditions and thus risking a deficient asylum procedure, Belgium was also found guilty. ${ }^{72}$ The Court concluded that transferring Member States can no longer presume the quality of the asylum procedure and overall compliance and harmonisation with the principles of the Union. The case highlighted what was already obvious: the divergent levels of protection European countries offer to asylum seekers. EU asylum law suffered a great blow from the most important international court protecting human rights, whose opinion must be taken into consideration, although it does not have jurisdiction in EU law issues. The Court stressed that when the issue of protecting the principle of non-refoulement and its corollaries arises, Member States of the Union are obliged to apply the sovereignty clause under the Dublin rules and refrain from sending asylum seekers back to Greece. The procedural rules of EU asylum law may in no way amount to a breach of States' obligations under international law and the protection of human rights. The burden of proof in assessing these risks is on the transferring States themselves.

A case with a very similar background was also reviewed by the Court of Justice of the European Union itself. A decision in NS \& Others $v$ $S S H D^{73}$ was brought a few months later in December 2011. An Afghan citizen seeking asylum in the EU was deported from the UK back to Greece as the country of his first entry into Union territory. The Court declared that the Common European Asylum System 'is based on mutual confidence and a presumption of compliance, by other Member States, with European Union law and, in particular, fundamental rights. ${ }^{\text {}}{ }^{4}$ However, if the transferring Member States 'cannot be unaware that systemic deficiencies in the asylum procedure and in the reception conditions of asylum seekers amount to substantial grounds for believing that the asylum seeker would face a real risk of being subjected to inhuman or

\footnotetext{
70 Cases Cruz Varas and Others $v$ Sweden App no 15576/89 (ECtHR, 20 March 1991) and Saadi $v$ Italy App no 37201/06 (ECtHR 28 February 2008).

71 Case TI $v$ The United Kingdom App no 43844/98 (ECtHR, 7 March 2000).

72 Often referred to as 'indirect refoulement'. L Lavrysen, 'MSS v Belgium and Greece (2): The impact on EU Asylum Law' (Strasbourg Observers 24 February 2011) <http://strasbourgobservers.com/2011/02/24/m-s-s-v-belgium-and-greece-2-the-impact-on-eu-asylumlaw/> accessed 9 July 2012.

${ }^{73}$ Joined Cases C-411/10 and C-493/10 N S v Secretary of State for the Home Department and ME and others $v$ Refugee Applications Commissioner, Minister for Justice, Equality and Law Reform (European Court of Justice, 21 December 2011).

74 NS \& Others (n 73) para 84.
} 
degrading treatment' (Article 4 of the Charter), ${ }^{75}$ they should not deport the asylum seeker despite the Dublin rules instructing them otherwise. In simpler terms, if an individual asylum seeker can rebut the presumption of compliance by demonstrating the possibility of being exposed to risk of inhuman or degrading treatment if transferred to a particular Member State, other States should use their discretionary power to take over responsibility for examining his asylum claim under the sovereignty clause of the Dublin Regulation. The Court was very careful in choosing its words in this decision, although upholding the opinion of AG Trstenjak that there was a risk of violation of human rights if the asylum seeker was returned to Greece. ${ }^{76}$ The Court did not in any way undermine the integrity of the common European asylum policy - it upheld the aforementioned presumption of compliance. However, it did take a step towards better protection of human rights in obviously deficient asylum procedures in certain Member States and thus made the irrebuttable presumption subject to examination and possible rebuttal by individual asylum seekers. It did not go as far as the Court in Strasbourg by subjecting every transfer to prior examination by the transferring State, but it did state that adherence to provisions on allocating responsibility for the asylum procedure cannot come at the expense of the fundamental rights of asylum seekers, now also guaranteed by the fully binding Charter.

The situation in Greece clearly shows that the Dublin system is about to collapse. The Secretary General of the ECRE, Bjarte Vandvik, stated that this is 'only a symptom of fundamental and far-reaching flaws inherent in the Dublin system'. ${ }^{77}$ The Union stated, under a certain amount of pressure from the international community and certain Member States, that there can be no margin of discretion and responsibility-shifting when dealing with the protection of the basic fundamental rights of asylum seekers. However, the cessation of all transfers to a certain Member State only emphasises that there is no real ground for a common policy on asylum in the EU: a system that would ultimately bring the highest level of protection. Partial solutions, such as the one at hand, may be effective in protection of human rights temporarily, but they cannot constitute an effective solution in the long-term.

\subsubsection{Asylum seekers and human rights}

The second argument indicating the inefficiency of the Dublin system is also connected with the guarantees of asylum seekers' human

\footnotetext{
$75 \quad$ NS \& Others (n 73) para 94.

76 NS \& Others (n 73) Opinion of AG Trstenjak.

77 See European Council on Refugees and Exiles (n 66).
} 
rights, or better to say, lack of them. The procedures for transfers back to the Member State of first entry, as well as general asylum-granting procedures, in a number of respects fail to provide the protection of rights guaranteed to asylum seekers by the Geneva Convention, European Convention for Human Rights and other international instruments. The Dublin Regulation, in combination with the other legislative acts of the Union, brings into question the compliance of the European asylum system with international human rights guarantees.

Firstly, detention has been increasingly used for securing transfers in a number of Member States, even though it is foreseen by European legislation only as a last resort in handling asylum seekers. Some Member States also detain returnees, and the overall conditions of detention throughout the Union rarely comply with the prescribed standards.

Secondly, the reception conditions, although harmonised at the Union's legislative level, still vary a great deal from one Member State to another. In some Member States, such as Greece, conditions are inadequate to the extent that even basic social assistance is not provided, or is not provided in a satisfactory manner. The same goes for healthcare, accommodation, basic survival needs, and providing asylum seekers with information about the procedure and other relevant rules of asylum policy in a way that they can understand, etc.

Thirdly, procedural safeguards are often disregarded, especially in the already mentioned cases of returnees to Greece, where asylum applications can hardly be renewed once the applicant has left the country. Furthermore, an effective opportunity to appeal against a decision in an asylum-granting procedure is often denied due to the non-suspensive effect appeals have according to current provisions.

Fourthly, the provisions for separated minors often disregard the best interests of the child, which is a widely recognised principle. Article 6 of the Dublin Regulation provides for the procedural responsibility of a Member State where the child has a family, but this provision is valid only in relation to the closest family members: the child's parents or guardians, or brothers and sisters who are minors. If a child does not have a close family member, the responsible Member Sate will be the one where the application for asylum was lodged, without taking into consideration other connections or interests a child may have in a different State. Children are also subject to Dublin transfers to countries where they lodged their first application. A number of Member States still do not provide basic facilities for a child's best interest, such as access to social services. ${ }^{78}$ There have been similar criticisms with regard to oth-

78 See European Council on Refugees and Exiles (n 60). 
er vulnerable groups of people, such as elderly people, disabled people, pregnant women, etc.

The final major human rights problem of the asylum system under the Dublin rules concerns the deficient provisions on family reunification. Articles 7 and 8 of the Dublin Regulation allow reunification of family members, and in such cases the rule relating to the country of first entry can be disregarded. However, such reunification can be carried out only under very restrictive criteria: the provisions only concern closest family members, ie parents and children who are minors. Parents cannot join their adult children or vice versa. All other family relations are also excluded from such reunification. Families are often separated for years due to delays in the procedures and processing of appeals.

A number of Member State governments and NGOs, the Parliament, UNHCR, ECRE and the Council of Europe have all raised concerns upon the inadequacy and inhumanity of the treatment of asylum seekers in certain Member States due to the application of the Dublin rules in combination with resistance to fully recognising their fundamental human rights. The entire system has been criticised as causing 'additional, unnecessary suffering to already traumatised refugees. ${ }^{79}$

The harmonisation process has not only resulted in lowering the protection guaranteed by international asylum law. The overall number of asylum applications processed in the European Union has decreased to a worrying extent. In the five-year period after the adoption of the Dublin Regulation, the number of asylum seeker claims fell more than $45 \%$, not all of which can be attributed to the social and political climate. Furthermore, being granted asylum often depends on the circumstances and Member State in which the asylum seeker has found himself: a system often referred to as the 'asylum lottery'. ${ }^{80}$ Even those granted asylum suffer from a serious lowering of standards in the procedure and deficiencies in guaranteeing their fundamental rights. All of these issues have culminated in increased numbers of illegal migrants entering and residing clandestinely in Union territory, which creates unnecessary detrimental consequences to an already detrimental asylum system.

What is clear, and what can be concluded from all the aforementioned issues, is that the measures of at least some Member States do not coincide with the spirit and final objective of the Geneva Convention in protecting asylum seekers' rights. They are still guided by the desire to

\footnotetext{
79 European Council on Refugees and Exiles, 'Sharing Responsibility for Refugee Protection in Europe: Dublin Reconsidered' (March 2008) 5 <www.ecre.org/component/downloads/ downloads/ 104.html> accessed 4 July 2012.

80 European Council on Refugees and Exiles (n 79).
} 
decrease this 'burden' on their internal functioning and to deal with the misuses of their national asylum policies. Even the Council's presidency affirmed this claim in their conference conclusions, by stating that the aim of the Dublin II system 'must remain the handling of abusive applications for asylum'. ${ }^{81}$ Can this approach really be seen as fulfilling the objective of the Geneva Convention and the international protection of refugees in good faith?

The entire system at the Union level cannot be referred to as a fair and balanced responsibility-sharing mechanism. Certain southern and eastern Member States face enormous pressure that they are unable to handle due to a lack of resources, the financial and practical weaknesses of their asylum systems and inadequate access to their asylum procedures. Other Member States frequently do not provide the necessary help and are often not co-operative in fully resolving matters. They simply rely on the transfer system and other Member States fulfilling the requirements for the international protection of refugees and disregard their own obligations under the Geneva Convention, ECHR and international law in general. Uneven distribution and lack of equitable responsibilitysharing measures is the European reality. Things only get worse when taking into account the still decisive but obviously false presumption that all Member States have the same high standards of refugee protection and that all their asylum-granting procedures fulfil the requirements of such protection. This kind of system cannot function for much longer. What is needed are consideration and replacement of the entire Dublin system, further harmonisation and an overall improvement in European asylum policy. Measures for a more balanced distribution of processing asylum claims are needed if the European Union is ever to achieve a real responsibility-sharing system. Likewise, better procedural guarantees are needed in a legislative and practical sense if the European Union is to achieve a truly common system based on the protection of the fundamental human rights of asylum seekers and refugees.

\section{A missed chance for improvement? Issues surrounding the Dublin III proposal}

Guided by the awareness of the inefficiency and downsides of the current Dublin system, the Commission issued a Proposal for a new, recast version of the Regulation establishing the criteria and mechanisms for determining the Member State responsible for examining an application (the so-called Dublin III Proposal) in 2008. ${ }^{82}$ Alarming reports and

81 The Greek Presidency of the Council of the European Union: The Challenge of Asylum and Immigration', (2002) 14(4) International Journal of Refugee Law 632, 636.

82 Commission (n 41). 
criticisms from the European Parliament, a number of NGOs, UNCHR, ECRE, Council of Europe, etc had shown the urgency of the situation and the Commission simply had to respond.

\subsection{The proposed amendments}

Several issues were addressed in the recast version of the Dublin Regulation. The proposed amendments were as follows.

Firstly, the scope of the application of the Regulation would be extended 'in order to include applicants for and beneficiaries of subsidiary protection'. Such an extension was considered necessary in order to 'ensure consistency with the EU aquis, namely with the Qualification Directive which introduced the legal notion of subsidiary protection'. ${ }^{3}$

Secondly, for reasons of ensuring the efficiency of the system, several deadlines were introduced, for example with regard to requesting other Member States to take responsibility. Some of the deadlines were shortened regarding requests and the answers to requests for information. Cessation of responsibility was clarified, as were the use of humanitarian and sovereignty clauses (now unified under the name 'discretionary clauses'), general rules on transfers, settlement of disputes between Member States, etc. ${ }^{84}$

Thirdly, the 'legal safeguards for persons falling under the Dublin procedure' were strengthened in order to 'enable them to better defend their rights'. Their rights to information were addressed in more detail, the right to legal assistance and/or representation was clarified, the right to ask for a personal interview was guaranteed, as well as the right to appeal against a transfer decision, with the appeal having suspensive effect under certain circumstances. Several provisions were 'clarified in order to guarantee respect for the principle of effective access to the asylum procedure'. Furthermore, it was emphasised that detention should not be used 'for the sole reason that a person is seeking international protection'. 85

Fourthly, to strengthen the right to family unity, the definition of family members was widened to include the beneficiaries of subsidiary protection, as well as all dependent relatives and unaccompanied minors, thus ensuring 'protection of the best interests of the child' and other vulnerable persons. These last two issues were removed from the humanitarian clause and inserted under the binding responsibility crite-

\footnotetext{
83 Commission (n 41) 7.

84 Commission (n 41).

85 Commission (n 41) 8.
} 
ria. Furthermore, the newly unified 'discretionary clauses' were revised, and several aspects of the procedure regarding its application clarified. The sovereignty clause was to be used mainly for humanitarian and compassionate reasons, and the humanitarian clause was to remain a general clause for preventing separation of family members. ${ }^{86}$

Fifthly, 'in order to better take into consideration the interests of unaccompanied minors' in asylum procedures, certain criteria were introduced for when Member States are dealing with the best interests of a child; reunification was to be guaranteed not only with the closest family members, but also with other relatives in a certain Member State. Furthermore, a mechanism for exchange of information relating to the transfer of minors and other vulnerable persons who need various forms of assistance was to be introduced. ${ }^{87}$

Finally, the Commission proposed a mechanism for dealing with the inefficiency of the previous system that had resulted in overburdening 'certain Member States with limited reception and absorption capacities' as well as a lack of 'adequate standards of protection in the responsible Member State, in particular in terms of reception conditions and access to the asylum procedure'. A new kind of procedure was to be introduced in the Dublin system which would allow for a temporary 'suspension of Dublin transfers towards the responsible Member State' under these circumstances. ${ }^{88}$

Before assessing the improvements the Proposal would introduce into the Dublin system, as well as the downsides of this still restrictive approach of the Commission, it has to be pointed out that the Council did not agree to the Commission's proposal in its most important aspects. ${ }^{89}$ The extension of the scope of the Regulation to include the beneficiaries of subsidiary protection and also certain time limits were accepted. However, the third, fourth and fifth issues were limited. The Council excluded from the third part of the amendments, dealing with legal safeguards, the suspensive effect of the appeals on transfer decisions, and limited the obligations of Member States using detention. It reduced Member States' obligations in providing information to asylum seekers, introduced exceptions from the right to interview, and weak-

86 Commission (n 41) 8-9.

87 Commission (n 41) 9.

88 Commission (n 41) 10.

89 Council of the European Union, 'Proposal for a Regulation of the European Parliament and of the Council establishing the criteria and mechanisms for determining the Member State responsible for examining an application for international protection lodged in one of the Member States by a third-country national or a stateless person (Recast) [First reading] - Preparation for the first informal trilogue', Interinstitutional File: 2008/0243 (COD) 8550/12 (10 April 2012). 
ened provisions dealing with legal aid. Dealing with the fourth part of the amendments, the Council rejected the wider definition of a family member, excluding from its scope married minor children or siblings. Regarding the fifth issue, the Council weakened the new provisions on protection of minors and the best interests of children. In addition, it excluded the ban on transfers of persons unfit to travel, weakened the usage of the humanitarian clause, and diminished the clause on responsibility for dependent family members. Dealing with the last issue and the temporary suspension mechanism, the Council completely rejected the Commission's proposal and replaced it with a weak instrument of 'early warning' to overburdened Member States. This is particularly problematic, since not only did it remove the possibility of providing even shortterm relief to pressurised Member States through the obligation of other Member States to suspend transfers, but it also directly contravened the opinion of the European Parliament and all international organisations and NGOs. Furthermore, it was also completely opposed to the established case law of the Court of Justice, in particular NS \& Others $v$ SSHD. The Council not only diminished the proposals of the Commission regarding strengthening safeguards and the better protection of family, children and vulnerable persons, but divested them of all their practical effect. ${ }^{90}$ It also disregarded the case law of the Court and all the recent developments in EU asylum law.

The result, as it seems at this point, is not a strengthening of the protection of human and asylum seekers' rights, but only a balancing of the existing, currently enforceable unsatisfactory level of 'protection'. The reasons for the Council's moves and such a restrictive approach cannot be understood by academics or critics. Even the Commission's proposals were criticised as not going far enough in granting asylum seekers the protection they are entitled to under international asylum guarantees. The Council's moves in weakening amendments providing already limited protection are incredible. It remains to be seen what the Parliament's response will be to the current weak version of the proposed amendments. It is to be hoped that the necessary steps will be taken to upgrade the level of protection for asylum seekers and to improve the current inefficient system. Only in this way can EU asylum law finally come into line with international guarantees. At present, success seems doubtful.

\subsection{Failing to address the problems}

In assessing criticisms of the proposed recast version of Dublin III, two major issues arise. Firstly, the human rights dimension of the Pro-

90 Peers (n 62) 5. 
posal still does not amount to a sufficient level of protection. The initiative of the Commission to propose improvements to the system was welcomed by all the major international institutions dealing with asylum and refugee protection, such as the European Council on Refugees and Exiles (ECRE), the United Nations High Commissioner for Refugees (UNHCR) and the Council of Europe. However, the Proposal did not, as all the institutions have argued, especially after the Council's modifications, go far enough to guarantee a full and fair examination of asylum claims, to better ensure family reunification, and better protect the best interests of children and other vulnerable persons. What the European Union seems to forget all the time is the harsh impact such procedures have on the human rights of asylum seekers, as well as their lives, especially families, children and vulnerable persons. Furthermore, the European Union still starts from the presumption that protection standards are equally present and applied in all Member States, a presumption which has clearly proved to be inaccurate in practice. Much more will need to be done in terms of the implementation and overall improvement of national asylum policies for such a presumption to be a valid starting point for a common asylum policy of the European Union based on a full and inclusive application of the Geneva Convention and other relevant international instruments of protection.

The second issue arises with the possible introduction of the temporary suspension mechanism in the Union's legislative order. The idea of such suspension has already been introduced by the Court of Justice in the aforementioned NS \& Others $v$ SSHD case, and supported by the European Parliament in its resolution on the evaluation of the Dublin system. ${ }^{91}$ However, suspending transfers to Member States that cannot guarantee a fair examination of asylum claims and are overburdened due to their geographical position and the state-of-first-entry concept of responsibility is still not enough to resolve the problem in its essence and does not deal with the fundamental flaws of the system. Such a solution can be effective temporarily by reducing harmful effects, but does not represent a long-term solution. The reports of the UNCHR, ECRE, Council of Europe and other institutions and NGOs imply that such a solution can be seen as an improvement, but is still not sufficient for the Dublin system to be considered a balanced and effective responsibility-sharing mechanism. ${ }^{92}$ They have proposed a distribution of Member

\footnotetext{
91 European Parliament, 'European Parliament resolution of 2 September 2008 on the evaluation of the Dublin system' $2007 / 2262$ (INI) point $7<$ http://www.europarl.europa. eu/sides /getDoc.do?pubRef=- / /EP / /TEXT+TA+P6-TA-2008-0385+0+DOC+XML+V0/ / EN> accessed 9 July 2012.

92 European Council on Refugees and Exiles, 'Comments from the European Council on Refugees and Exiles on the European Commission Proposal to the Recast Dublin Regula-
} 
States' responsibilities based on integration and better compliance with the principle of solidarity as one of the main principles of the European Union as contained in Article 80 TFEU. ${ }^{93}$ In this way, the Dublin system would finally be 'reconnected with its original objective, which was to reduce the harm to asylum-seekers and avoid uncertainty among EU Member States on responsibility for addressing asylum applications.. ${ }^{94}$ What they suggest is responsibility being taken by a Member State with which the asylum applicant has some sort of connection, such as family ties, language skills, cultural or educational connections, ${ }^{95}$ which would definitely promote integration as one of the main objectives of the Union, help the asylum seekers to better integrate into their accepting countries, relieve border Member States of pressure, as well as solve the problems of secondary and irregular movements of asylum seekers. If there are no such connections, the proposal of a free choice for the asylum seeker could also be taken into consideration. Even the Directorate General for the Internal Policies of the European Parliament has recommended such voluntary relocation as a way of ensuring better effectiveness of the responsibility-sharing mechanism. ${ }^{96}$

What is also needed, besides changing the distribution of responsibility, is greater financial compensation for Member States that face the pressure of mass inflows of asylum seekers, as well as strengthening individual national systems. Only in that way can any kind of responsibility-sharing mechanism really work and only in that way can fundamental asylum seekers' rights be fully guaranteed. The European Union as a whole is not overburdened, according to the Council of Europe's report, in comparison to other parts of the world. ${ }^{97}$ Solutions are possible. The question, however, remains whether the European Union is capable of such a substantive reconsideration of its system of responsibility for asylum applications. So far, Member States have not shown any willing-

tion' (April 2009) <http://www.ecre.org/topics/areas-of-work/protection-in-europe/133. html $>$ accessed 9 July 2012; see also Council of Europe, Office of the Commissioner for Human Rights (n 67).

93 Council of Europe, Office of the Commissioner for Human Rights (n 67).

94 International Commission of Jurists, Workshop on Migration and Human Rights in Europe, 'Non-refoulement in Europe after MSS v Belgium and Greece' (Summary and Conclusions) (July 2011) $7<$ http://www.icj.org/dwn/database/ICJWorkshopSummaryFinal.pdf> accessed 4 July 2012.

95 See European Council on Refugees and Exiles (n 92) 4; European Council on Refugees and Exiles (n 79) 4.

96 European Parliament, Directorate-General Internal Policies, Policy Department C, Citizens' Rights and Constitutional Affairs, 'What system of burden-sharing between Member States for the reception of asylum seekers?', Study, PE 419.620 (22 January 2010) 146 <http://personal.lse.ac.uk/thielema/Papers-PDF/EP-BS-Study-FullReport-final.PDF> accessed 9 July 2012.

97 See Council of Europe, Office of the Commissioner for Human Rights (n 67) 2. 
ness to take any major steps. 'Whatever the political obstacles to change, such a single-minded preference for the status quo could only be defensible on the premise that the Dublin system [has] worked by and large satisfactorily. ${ }^{98}$ Without any doubt it can be claimed that Member States have their own reasons for such a restrictive approach towards change. However, can it really come at the cost of fundamental human rights? Or better to say, for how long can such a restrictive approach have primacy over the international obligations of Member States arising from the Geneva Convention and the principle of non-refoulement inherent in Article 3 ECHR? As concluded by the ECRE:

Ultimately the current Dublin system must be abolished altogether. By linking responsibility for asylum applications with responsibility for entry controls, the Dublin system is in conflict with the aim of burden-sharing as envisaged in the Amsterdam Treaty objectives and does not provide a balanced way of addressing flows of asylum seekers. As well as placing individual asylum seekers at risk of refoulement, the Dublin system is inefficient and resource-intensive. ${ }^{99}$

The Dublin III proposal, in its current state after the Council's amendments, does not only disregard the problems of the system and the reports and recommendations of its own institutions as well as external ones, but has also abolished the possibility of a suspension mechanism as a temporary solution to the problem. Why the Council missed the opportunity to create a more efficient and balanced responsibility-sharing system which would consequently provide better protection to asylum seekers and thus better fulfil the objective of the Geneva Convention and the obligations of Member States arising from it, is a question without any obvious answer. It still remains to be seen how the problems will be resolved and what kind of system the final provisions of Dublin III will create. However, the current position cannot be seen as optimistic. The concern must be raised whether the European Union has once again failed to address the inefficiency of the responsibility-sharing mechanism and consequently again failed to provide asylum seekers with the protection they are entitled to under the Geneva Convention, the European Convention of Human Rights and other relevant international instruments.

\footnotetext{
98 European Parliament, Directorate-General Internal Policies, Policy Department C, Citizens Rights and Constitutional Affairs: 'Reflection Note on the Evaluation of the Dublin System and on the Dublin III Proposal' PE 410.690 (March 2009) $1<$ http://www.europarl. europa.eu/committees/en/studiesdownload.html?languageDocument=EN\&file=25131> accessed 9 July 2012.

99 European Council on Refugees and Exiles, 'Summary Report on the Application of the Dublin II Regulation in Europe' AD2/3/2006/EXT/MH (March 2006) 25 <http://www. ecre.org/component/downloads/downloads/108.html> accessed 4 July 2012.
} 


\section{Conclusion}

The transfer of competences in asylum policy to the European Union has been guided by the objective of establishing a Common European Asylum System which would ensure that appropriate protection is granted to all persons in need of such protection, as required by the Geneva Convention and other relevant international treaties on the protection of refugees and asylum seekers. The European Union has developed a number of legislative instruments regulating asylum policy at the substantive and procedural levels. The main issue arises in the allocation of responsibility for the enforcement of asylum procedures between the real actors of asylum policy: the Member States.

The Dublin Regulation of 2003 established the criteria for determining which Member State is the one responsible for examining lodged asylum applications and accepting asylum seekers under the principle of the State of first entry into the Union's territory, save for certain very limited reasons of family reunification and issuance of a valid residence permit. The Dublin system has, in almost 10 years of its application, showed itself to be inefficient in bringing about a fair and balanced responsibility-sharing system, as required in the Treaty provisions and as defined under the Union's asylum programmes.

The Dublin allocation of responsibility is based on the incorrect presumption that all Member States provide an equal amount and quality of protection, while practice shows many divergences in national policies, differing approaches to the implementation of refugee protection standards, inadequate transposition or simply inadequate practice. The result is uneven burdens for Member States on the southern and eastern borders of the Union. These are countries which are often least able to handle this kind of pressure due to insufficient resources and the financial and practical weaknesses of their asylum systems and inadequate access to their asylum procedures. Geographical position has become the defining principle, while the ability to handle the inflow of asylum seekers has become irrelevant. The states in question respond to the pressure they are exposed to by limiting access to and the conditions of the asylum-granting procedure. An obligation to guarantee the right to a fair hearing thus often comes into question. The most problematic and debated case of such overburdening with inflows of asylum seekers from third countries and with their transfer from other Member States under the Dublin rules is that of Greece. The situation escalated to such a point that the most important international organisations such as the Council of Europe, the UN's High Commissioner for Refugees, the European Council on Refugees and Exiles, the European Court of Human Rights, as well as the Court of Justice of the European Union itself demanded 
the cessation of all transfers to that country, claiming that the fulfilment of Member States' obligations under the Dublin rules cannot come at the cost of asylum seekers' fundamental rights, such as access to a fair and effective asylum procedure. Cessation of transfers to a certain Member State only emphasises that there is no real ground for a common policy on asylum in the EU and a system that would ultimately bring the highest level of protection. Partial solutions, such as the one at hand, may be effective in the protection of human rights temporarily, but they cannot constitute an effective solution in the long-term.

In addition, the procedures for such Member State transfers, in combination with the overall asylum-granting procedure, by not providing sufficient guarantees also bring into question the protection of internationally guaranteed refugee rights as well as basic fundamental human ones. In a number of respects, the EU fails to provide the protection of rights guaranteed to asylum seekers by the Geneva Convention. There are still a number of detention issues, deficient reception conditions, often disregarded procedural guarantees, non-consideration of the best interests of children, barriers to family reunification etc, raising concerns about the adequacy and humanity of the treatment of asylum seekers in the European Union.

What is clear is that the entire system at the Union level cannot be referred to as a fair and balanced responsibility-sharing mechanism. This kind of system cannot function for much longer and what is needed is the reconsideration and replacement of the entire Dublin system, further harmonisation, strengthening of the individual national asylum systems and the overall improvement of European asylum policy. More precisely, the EU needs to develop measures for a more balanced distribution of processing asylum claims as well as better procedural guarantees in a legislative and practical sense.

An attempt to improve the Dublin provisions was made by the Commission's proposal on the recast version of the Regulation in 2008. Certain improvements were introduced regarding procedural safeguards and the protection of families, children and vulnerable persons, as well as regarding the obligation to refrain from transfers to countries that cannot guarantee a fair examination of asylum claims and are overburdened due to their geographical position and the state-of-first-entry concept of responsibility. However, the most important ameliorations of the system were rejected by the Council. The Proposal, especially after the Council's restrictions and modifications, did not go far enough to guarantee a full and fair examination of asylum claims, to better ensure family reunification and protect the best interests of children and other vulnerable persons. Even the proposal of suspending transfers to over- 
burdened Member States, ultimately rejected by the Council, is still not enough to resolve the problem in its essence and does not deal with the fundamental flaws of the system. Such a solution can be effective temporarily by reducing harmful effects, but does not represent a long-term solution.

To summarise, the Dublin II Regulation, by failing to provide an effective mechanism for responsibility allocation, has made the entire asylum system in the European Union dysfunctional and of questionable conformity with international standards of protection of asylum seekers and refugees. The Commission and especially the Council, according to the current position of the Dublin III Proposal, have missed the opportunity to create a more efficient and balanced responsibility-sharing system which would consequently provide better protection to asylum seekers and thus better fulfil the objective of the Geneva Convention as well as the obligations of Member States arising from it. The Proposal and entire initiative could be seen as an announcement that the European Union is aware of the downsides and defects of the current asylum system, and that it has shown a willingness to ultimately confront them and, hopefully in the near future, to resolve them. Possible but questionable future achievements, however, cannot and do not prevail over the worrisome status quo. The European Union has once again failed to address the inefficiency of the responsibility-sharing mechanism and consequently again failed to provide asylum seekers with the protection they are entitled to under the Geneva Convention, the European Convention of Human Rights and other relevant international instruments. 